\title{
A számítógép és az irodalom
}

A technikai médiumokkal bekövetkező változás az írást megfosztja monopolhelyzetétől. A konvencionális könyvnyomtatás uralmát is felváltja a lézeres nyomtatás által demokratizálódott produkció, „az írott szöveg legmagasabb szintű előállítása” (Papp Tibor, Avantgárd szemmel az irodalmi világról, 2008): írók, költők nyomtatásra kész műveket szerkesztenek, s így nemcsak a szerzők, de az olvasók vizuális kultúrája is finomodik. A papír mellett megjelenik tehát egy új mediális jelhordozó hatalom, egy új „üzenetközvetítő”: a számítógép. Az új médium az irodalom perspektíváit is kiszélesíti: felerősödik a vizualitás, színes, dinamikus, hangos művészi alkotások születnek, s egy működő program akár szabályos, klasszikus versformák generálására is képes. A tanulmány szól a számítógépes irodalom történetéről, a világháló által megújult numerikus irodalom új irányairól, s Papp Tibor művein keresztül (elsősorban a Disztichon Alfa 16 billió alkotásával, s a Hinta-palinta című dinamikus költeménnyel) bemutatja a számítógéppel generált irodalmi művek sajátosságait.

Kulcsszavak: íráshordozók, "grafoszférák", számítógépes irodalom, automatikus versgenerátor, versgenerálás, dinamikus kép-, szöveg- és hangversek, gyürük, logo-mandalák, numerikus költészet

\section{Szerzői információ:}

Kelemen Erzsébet

Író, költő, drámaíró és tanár, Debrecenben él. A Debreceni Egyetemen irodalomtudományi doktori tanulmányokat folytat. Kutatási területe a kortárs vizuális költészet. Képverseiból több helyen rendeztek kiállítást. Szakirodalmi publikációi mellett számos szépirodalmi kötete jelent meg: versek, képversek, novellák, ifjúsági történelmi regény, dráma Teleki Pálról, monodrámák. 2007-ben díjat nyert a Magyar Írószövetség és a Honvédelmi Minisztérium által meghirdetett szépirodalmi pályázaton. Legutóbbi könyvei a Viasspecsét és a Happy Birthday!. Jelenleg a Papp Tibor munkásságát bemutató monográfiáján dolgozik.

E-mail: kelemen.e@freemail.hu

Így hivatkozzon erre a cikkre:

Kelemen Erzsébet. „A számítógép és az irodalom.”

Információs Társadalom IX, 1. szám (2009): 47-63.

$=$ https://dX.doi.org/10.22503/inftars.IX.2009.1.5


Kelemen Erzsébet

\section{A számítógép és az i rodalom}

\section{Modellek versengése}

Az 1900-as évek médiatörténeti váltása, az új „lejegyzési rendszer”, a hangot és a látványt rögzítő technikai eszközök megjelenése a szavak médiumspecifikus karakterére irányítja a figyelmet. S bár a jel érzékisége mint a „költőiség” médiuma nem oltja ki azt a mediális transzformációt, amely lehetớvé teszi a költối nyelv rögzített megjelenítését az audiovizuális médiumokban, a szó státusának, mediális lefordíthatóságának megváltozása mégis „,gyökeresen más helyzetben láttatja az irodalmat”. ${ }^{1}$ Sót, a szavak technikai eszközökbe való beiródásával önálló irodalmi múfajok teremtôdnek meg. Létrejöttük és elkülönítésük a változások egymásra ható törvényszerúségeiból vezethetố le.

1997-ben Jacques Derrida egy interjú alkalmával az irodalom specifikus médiumáról szólva a korábbi és az újonnan megjelenó modellek sokaságát például „technikai” és „természetesebb” elnevezésû csoportokra osztotta. Így a grafikai mellett megkülönböztette a fényképezógép, a mikroszkóp stb. világát jelentő optikait, s „természetesebbnek" nevezte az organikus nyomokat az agyban, az emléknyomokat és a génvagy biográfiákat a testen mint hordozón. Ezek a modellek, bár idónként lemondanak a papírról, egyaránt a grafoszférához tartoznak, amely valamilyen felületet feltételez, megkívánja egy hordozó materialitását. ${ }^{2}$

Az új technikai médiumok megjelenése és egymással való versengése a múvészetek egymás közti viszonyát is megváltoztatta. A fotográfia a festészetnek, a film a színházmúvészetnek és a regény múfajának jelentett kihívást, a hírközlés eszközei pedig lecsökkentették vagy megszüntették a térbeli távolságot, s a tagolásban, az észlelésben teremtettek új világot. Az emberi érzékelőszerveknek mindez ugyancsak kihívást jelentett. A telefon is új világba helyezi az embert azáltal, hogy a hangot, a nyelvi jeleket leválasztja a testról. Proustnak Az eltünt idô nyomában címú regényében Marcel a nagymamával való telefonbeszélgetése során tapasztalja meg ezt a sajátos jelenlétet és távollétet, az új dimenziót, a présence és az absence állandó kettősségét. A nagymama hangjának a leírásával az író metafizikai távlatokat nyit, létösszefüggéseket tár fel. Azt a felismerést osztja meg velünk, hogy az emberi közelségben mindig ott van a távolság, és soha sincs tökéletes azonosság. A távollétnek a jelenlétével pedig a halál idézốdik fel, az a végsố különválás, amikor a test olyan távolságba távozik, ahonnan már a hang sem tér vissza.

' Kulcsár-Szabó Zoltán: Metapoétika. Önprezentúció és nyelvszemlélet a modern költészetben. Budapest-Pozsony, 2007, Kalligram, 34. A mediális transzformáció jelen van ,a hallucináló vagy a képzclet imaginárius közegeiben vagy valóságosabb akusztikus vagy vizuális effektusokban” (uo.).

${ }^{2}$ Jacques Derrida: A papír (a)vagy én, tudják... In Bónus Tibor - Kelemen Pál - Molnár Gábor Tamás (szcrk.): Intézményesség és kulturális közvetítés. Budapest, 2005, Ráció Kiadó, 390, 394. 
A múvészetekról nem lehet közvetítő közegüik nélkül beszélni. A médiumok viszont nem egyszerú hordozóeszközök. A gyógyításban a vivôközeg másodlagos: a beteg a gyógyszert megkaphatja tabletta vagy injekció formájában. Mindez nem ilyen vehikulumszerú a múvészetben.

1766-ban a német felvilágosodás klasszikus alkotója, Lessing a Laokoón vagy a festészet és költészet határairól címú esszéjében megállapítja, hogy a képzőmúvészet nem képes az idő megjelenítésére: „A festészet a maga egyidejú kompozícióiban a cselekménynek csak egyetlen pillanatát ragadhatja meg, ezért a legjellemzóbbet kell választania, melyból az előzóket is, a következóket is a legjobban lehet érteni." ${ }^{3}$ Így van ez a Laokoón-csoport esetében is: az apa küzd a kígyókkal, miközben balján az egyik fiút éppen megtámadja a kígyó, jobbján pedig a másik fiú már lehanyatlik. A mú az idő három fázisát súríti tehát egybe. Az irodalom viszont a tér mellett az idốt is ki tudja terjeszteni a hang, a szó segítségével.

Lessing óta csak ritkán kérdőjelezték meg annak a tételnek az érvényességét, miszerint a képzốmúvészet a térhez, az irodalom pedig az idóhöz van kötve. „A festészet és a költészet határain" az új müncheni iskola alapítója, Kurt Badt lépett túl. Kimutatta az összefüggést az orientáció és a képfelépítés között, s szabályként egy balról jobbra és egyben alulról fölfelé tartó irányultságot állapított meg a kép befogadási, „olvasási” irányaként. Ennek a módszernek a heurisztikus értéke éppen abban rejlik, hogy a kép szukcesszivitásáról is lehet immár beszélni. A képi és a szöveges múalkotás megértő észlelése között tehát megegyezés van: „Mindkettő lineáris, azaz szukcesszív, és ugyanakkor szimultán is, vagyis mint egészet is felfogjuk." ${ }^{4}$ Dürer Apokalipszis-sorozatát elemezve Peter Krüger is kimutatja, hogy a kép szukcesszív észlelése (a képolvasás) és az ábrázolt történés (a kép cselekménye) egy képi elbeszélés zárt „sztorijává” kapcsolódik össze. Krüger ebból arra a következtetésre jut, hogy egy képzómúvészeti alkotás ugyanúgy költối eljárást alkalmazhat, mint egy szöveg. ${ }^{5}$ Az irodalom és a képzómúvészet hordozóeszközei (a hang, a szó, a vászon, az anyag stb.) tehát nem csupán eszközök, nem egyszerúen feljegyeznek és tárolnak valamit, hanem a tér és az idó kiterjesztésének a lehetôségei.

Történetileg az elsố mediális instrumentum az írás, amely allegorikus megkettôződést hoz létre a beírás mozzanata és az azt hordozó anyag között. Az írás ugyanis nem puszta rögzítése a szóbeli eseménynek, hanem „olyan technológiai vagy mediálisarchiválási játéktér, amely maga is meghatározza és formálja az általa közvetített szemiózis hozzáférhetôségét". "(Walter J. Ong az emberi testet is médiumnak fogja fel. A kultúraszületés korai szakaszában ugyanis épp az emberi test válik jelhordozó felületté, azaz médiummá. Gondolhatunk itt akár a testfestésre is, amely nem egyszerúen

${ }^{3}$ Gotthold Ephraim Lessing: Laokoon oder Über die Grenzen der Malerei und Poesie (1766). Magyarul: Laokoón vagy a festészet és költészet határairól. In Balázs István (vál.): Gotthold Ephraim Lessing válogatott esztétikai irrísai. Fordította Vajda György Mihály. Budapest, 1982, XVI. fejezet, 253.

4 Peter Krüger: Bevezetés a múvészettörténeti elbeszéléskutatásba: a festészet és a költészet határai. Fordította: Rózsahegyi Edit. In Thomka Beáta (vál.): Narratíurik. 1. Képleírís, képi elbeszélés. Budapest, 1998, Kijárat Kiadó, 103-108, 113.

${ }^{5}$ Peter Krüger: i. m. 116.

' Lốrincz Csongor: Medialitás és diskurzus. Az 1900-as lejegyzőrendszer. Friedrich A. Kittler: Aufschreibesysteme 1800/1900. In Kulcsár Szabó Ėrnố - Szzirák Péter (szerk.): Történelem, kultúra, medialitás. Budapest, 2003, Balassi Kiadó, 156-173. 
díszítő funkciót tölt be, hanem társadalmi, kulturális, rituális jelek, üzenetek közvetítôje lesz.) Az írás a jelentésben, a hangban és a képzeletben való szintetizálhatóság dekonstruálásából keletkezik. Így válik anyagszerúvé. Ha a hangot felvevókészülékkel rögzítjük vagy számítógépen állítjuk eló, akkor egy új medializálódási folyamatba kerül bele. Az akusztikai ingerreakciók mellett a nyelv másik dimenziójának, a vizuálisnak a rögzítése is más mediális-szemiotikai státust hív elő.

Nincs tehát médium önmagában, csak intermedialitás, hiszen - ahogy a jelrögzítési mechanizmusok rendszerét vizsgálva Friedrich Kittler is megfogalmazza ${ }^{8}$ - minden médiumnak szükségképpen megképződik a másika, amely az aktuális médium szubverziójaként, illetve megelőzöttségeként nyilvánul meg. Ami ugyanis verbális, az vizualizálódik, és fordítva, ami vizuális, az verbálissá válik. S a technomédiumok feltalálása révén új auditív és vizuális érzékterületek küilönülnek ki az irodalomból.

A technikai médiumokkal bekövetkezô változás az írást megfosztja monopolhelyzetétól. A konvencionális könyvnyomtatás uralmát is felváltja a lézeres nyomtatás által demokratizálódott produkció, „az írott szöveg legmagasabb szintû́ elóállítása”: írók, költốk nyomtatásra kész múveket szerkesztenek, s így nemcsak a szerzók, de az olvasók vizuális kultúrája is finomodik. ${ }^{9}$ A papír „visszahúzódása” viszont a papírnak nem a halálát, csak a redukcióját jelenti (ami nem azonos a ritkulással!), hiszen a „technológiai kalandok” - bár túlvisznek minket a papíron - fel is szabadítják olvasásunkat „a papír múltbéli forrásainak a retrospektív kiaknázására". ${ }^{10}$

\section{Digitális irodalom}

Az írás numerizálása és digitalizálása során valójában a számítógép képernyoójén, egy elektronikus közegben alkotjuk újra a papír szimulakrumát, a papír papírját. Ha a papír teste nincs is jelen materiálisan, mégis „továbbra is megkísérti [...] a számítógép képernyójét, és minden vitorlás vagy vásznas navigációt az interneten”. A papír normái, alakzatai - így a vonal, a bekezdés, a margók, az oldaltördelés stb. - ugyanis adottak a képernyố számára. ${ }^{11}$

A „szóbeli-írott” üzenet új státusa a látható nyelv, amely ugyancsak a jelek dekódolását jelenti, papírral vagy papír nélkül. A látható nyelvnek két változatát különíthetjük el: a statikust, az állót, amely kétdimenziós, nincs lineáris olvasata, tehát hangosan nem reprodukálható, valamint a hangot és a vizualitást egyesítő kinetikust, azaz a mozgót, amely a programozott számítógépes költészet nyelve.

Moholy-Nagy László, a konstruktivizmus markáns képviselóje a filmmúvészet kapcsán már 1922-ben szól a kinetikus alkotásmódok kommunikatív erejéról: az „idômozzanat és annak szüntelenül továbbfutó tagolása fokozott aktivitásra készteti a nézốt, aki [...] arra kényszerül, hogy önmagát bizonyos mértékig azon nyomban megkettôzve képes legyen optikai élményeit ellenốrizni és egyidejúleg továbbfejleszteni. A

${ }^{7}$ Uo.

${ }^{8}$ Uo.

"Papp Tibor: Hogyan képzelem el a következő huszonöt év irodalmát. In uố: Avuntgárd szemmel az irodalmi vilúgról. Budapest, 2008, Magyar Múhely Kiadó, 40.

${ }^{10}$ Jacques Derrida: i. m. 389.

"Jacques Derrida: i. m. 387. 
kinetikus megformálás, hogy úgy mondjuk, könnyebben serkenti az emberben azt az aktivitás iránti igényt, hogy új életszemléleti mozzanatokat azonnal magáévá tegyen." 12 A kinetikus „,nyelvet” használó programozott számítógépes költészet is ezt az új kommunikatív magatartást prezentálja.

A papír mellett megjelenik tehát egy új mediális jelhordozó hatalom, egy új „üzenetközvetítô": a számítógép. Az új médium az irodalom perspektíváit is kiszélesíti: az internet például új esélyeket ad a szerzóknek és az olvasóknak, folyóiratok online kiadásai jelennek meg, irodalmi portálok, szerzói honlapok és blogok adnak publikálási és olvasási teret, s a szövegeket, a szövegekkel kapcsolatos információkat is könnyen elérhetốvé teszik. Mindez „a versnyelvre és a -formákra is hatást gyakorló esemény”, hisz egyszerúsödnek a formák, a szövegek megrövidülnek, s a kor jellemző szavai, szófordulatai is beszúródnek a költói nyelvbe (lásd: „mentés másként”). ${ }^{13}$

Az elektronikus múvészeteket, a numerikus irodalmat és költészetet vizsgálva a francia kutatók két irányt különítenek el: a múvek megjelenését a világhálón és a feltelepítés gyakorlatát. A feltelepítések tanulmányozásával még ritkábban találkozhatunk a szakirodalomban. A francia Print on Screen 2000-ben három fő múvet mutatott be. Az egyik a Text Rain (Szövegesố) címú interaktív installáció, amelyben az alkotók, Camille Litterback és Romy Achituv szavakat és sorokat jelenítenek meg. A performance-ban témájuk a test és a nyelv, melyek ugyanazt a teret osztják meg - a valódi és a virtuális között -, és ugyanannak a gravitációs törvénynek vannak alávetve. Az irodalom testet ölt, a szöveg követi a formák körvonalait, s az olvasás szellemi és fizikai gyakorlattá válik. ${ }^{14}$ A performer ugyanis saját magát látja a videóban, ahol betúesố hull rá. ${ }^{15} \mathrm{~A}$ másik mú David Small és Tom White japán kertje (An Interactiv Poetic Garden): itt „a víz egy csatornán folydogál, míg el nem éri a tavacskát. A szöveg ugyanúgy folyik, mint a vízsugár. A közönség (egy érintési pont által) aktiválhat egy fényt, amely blokkolja a szavakat, vagy elóidézhet más, szemantikailag kapcsolódó kifejezéseket." ${ }^{16}$ Az alkotók tehát elemeket és folyamatokat idéznek fel. Ebben a múben a fogalmak látszólagos ellentmondásait kölcsönhatással, szemlélôdéssel és meditációval oldhatjuk fel. A harmadik mú Christa Sommerer és Lauret Mignonneau Life Spaces II. címú alkotása, amelyben a szavak a képernyoón megjelenített numerikus „lényekké” válnak. A lények szavait (, a genetikus kódot”) alkotó betúk egyben a lények táplálékául is szolgálnak, amit a közönség biztosít azáltal, hogy leírja óket. „A Life Spaces II. a mélységbe taszítja a kód fogalmát, és a szöveg mint táplálék metaforája kapcsolatot teremt a test és a szellem között." ${ }^{17}$ A numerikus telepítés az olvasó és a szöveg kölcsönhatása által lehetôséget ad a

\footnotetext{
${ }^{12}$ Moholy-Nagy László: Fiestésæet-fénytépészet - film. Ford. Mándy Stefánia. Budapest, 1978, Corvina, $21-22$.

${ }^{13}$ Bedecs László: „Bélyeg helyett kukac van”. Költészet a digitális korszakban. Palócföld, LIV. évf., 2008/2, 37-38.

${ }^{14}$ Annick Bureaud: Littérature et poésic numériques: le retour. Art Press, déc. 2000, 263. Ford. Papp Nóra. (Elsố magyar közlés.) Bureaud példaként Jeffrey Shaw Legible Cityjét említi.

${ }^{15}$ Vajon a betúesốt előzetesen vették fel videóra, s az clőadás során csak bejátszották, vagy számítógép adta ki véletlenszerúen a betúket, azaz lineáris vagy nem lineáris alkotásról van-e szó? Ez az alkotók titka.

${ }^{16}$ AnnickBureaud: i. m. 263.

${ }^{17}$ Uo.
} 
különbözố tereknek (a valódinak és a virtuálisnak, a szelleminek, a fizikainak, valamint a szemantikainak) az összeütköztetésére és ezek megosztására. ${ }^{18}$

Az új médium által tehát felerősödik a vizualitás, színes, dinamikus, hangos múvészi alkotások születnek, s egy múködő program akár szabályos, klasszikus versformák generálására is képes. S ez utóbbi alkotói folyamatban a számítógép már nem egyszerú információtároló és információmegjelenítő eszköz, hanem mindez már a számítógépes költészet megszületését jelenti.

\section{Számítógéppel generált versek (A számítógépes költészet mikrotörténete)}

A gép memóriájába betáplált versgeneráló program első megalkotója Theo Lutz, aki 1959-ben a stuttgarti múszaki fő́iskolán, az akkor még csupán negyven szó befogadására és kombinációjára képes számítógépen próbálkozott a múfaji paradigmaváltással. 1964-ben Montrealban La machine à écrire (Az író gép) címmel már megjelenik az elsô számítógépen generált verseskötet is Jean A. Baudot „tollából”. Pierre Moretti és ugyancsak Jean A. Baudot 1967-ben már számítógéppel generált szövegú színdarabot alkot Équation pour un homme actuel címmel, s Emmett Williams az Isteni színjáték szavaiból egy 213 soros Dante-litániát készít (1965) a költő születésének hétszázadik évfordulójára. Megemlíthetjük még e történeti sorban az első versantológiát is, amely 1973-ban Computer Poems címmel jelent meg, Richard W. Bailey szerkesztésében (Protagonnising Press, Michigan, USA). A francia OULIPO csoport pedig az egyik alapítója, Raymond Queneau Százezer milliárd költemény (Cent mille milliards de poèmes) címú múvét vitte számítógépre. A programot 1975-ben mutatták be a brüsszeli Euralia nemzetközi kiállításon.

Jean-Pierre Balpe Poèmes d'amour par ordinateur (Szerelmes versek számítógéppel) címú programjával lírai költeményeket generál. Egy másik alkotásában 620 szerkezeti struktúrával, a számítógépbe betáplált több ezer szó variálásával meseszövegek több milliárd változatát hozza létre, s 1536 petits contes parfois tristes ou pervers címú könyvében ezekból véletlenszerúen válogatva 1536 „olykor szomorú, olykor perverz” "19 rövid mesét tesz közzé. Jacques Roubaud Alexandrins artificiels (Mesterséges alexandrinusok) címú programja klasszikus szerzók múveiból használ fel több ezer szót, s ezekból generál szabályos alexandrinusokat. ${ }^{20}$ A 80 -as években Claude Maillard Mnesis címmel számítógépes hangverset alkot, s a francia Minitel-hálózaton már megjelenik az elsố elektronikus kiadvány is Art Accès címmel, amely közel száz alkotó munkáját teszi elérhetôvé. ${ }^{21}$

${ }^{18}$ Uo.

19 Petốfi S. János: A hipertextuális irodulom a perszonal computer eltcrjedt alkalmazásának korszakában. http://www.jgytf.u-szeged.hu/ vass/szemm082.htm

${ }^{20}$ Papp Tibor: Disztichon Alfa. Elsö magyar automatikus versgenerátor. Budapest, 1994, Magyar Múhely, $18-19$.

${ }^{21}$ Papp 'Tibor: Irodalomról az internet árnyćkában. In Avantgárd szemmel az irodalmi világról. Budapest, 2008, Magyar Múhely Kiadó, 62. 


\section{Az első magyar automatikus versgenerátor}

A magyar vizuális irodalom elsó számítógépen generált, dinamikus képversének a megalkotója Papp Tibor, aki elókeló helyet foglal el a világirodalom számítógépes múvészetében, s az elsố nemzetközi, csak számítógépen generált múveket közlő irodalmi folyóiratnak, az elöször 1989 januárjában megjelent párizsi Alire-nek egyik alapítója és mindmáig szerkesztôje.

Alexandre Gherban az új költészet úttörôjének nevezi Papp Tibort, azon ritka szerzók egyikének, akinek a munkásságában ,egyenlő súllyal szerepelnek a papírra fektetett, az írott és a számítógépen kreált irodalmi múvek", s akinek korszakalkotó dinamikus költeményét elismeri minden „költészettörténelem” és minden számítógépes irodalmat taglaló írás is. ${ }^{22}$ A múvet a szerzó 1985 -ben mutatta be a párizsi Georges Pompidou Központban Les très riches heures de l'ordinateur, $n^{\circ} 1$ címmel, II. (Jó) János király fiának, Jean de Berry hercegnek (1340-1416) a hóráskönyvét idézve (Nagyon gazdag órák). Ugyanebben az évben a Magyar Múhely elsố magyarországi találkozóján, a kalocsai Schöffer-szemináriumon már látható volt Papp Tibor első magyar nyelvú dinamikus képverse, a Vendégszövegek számitógépen $n^{\circ} 1$ is.

Papp Tibor egy alkalommal, cipófúzés közben, a frissen megszületett disztichonjának a hexametersorát idézte fel, s az egyik elfelejtett szót spontán egy másikkal helyettesítette be. A véletlenszerú szócsere más színt adott a sornak, amely ugyanolyan erejü, esztétikailag egyenrangú volt az előző változattal, hangulatilag és tartalmilag mégis egészen újszerúen hatott. Ezen felbuzdulva harmadik, negyedik, ötödik szóváltozattal, sốt a disztichon többi szavának a felcserélésével, behelyettesítésével is kísérletezett. Így született meg az elsô automatikus versgenerátor, a Disætichon Alfa. ${ }^{23}$ A kétezer-négyszáz szóból virtuálisan megalkotott disztichonok mágneses lemezét amely terjedelemben mintegy hatmilliárd verseskönyv anyagát rejti - Magyarországon 1994-ben vehették kézbe az olvasók.

A Disztichon Alfa megnyitott lemezének számítógépes oldalait „lapozgatva” a befogadók valóban a hexameterek és pentameterek egymást követố sokaságában gyönyörködhetnek, a szabályos formában és a tartalomban egyaránt. A generált versek kinyomtatására ugyan itt nincs lehetôség (erre vonatkozó parancsot a program nem tartalmaz, hiszen ez ellenkezne a számítógépen generált múvek törvényszerúségével!), de „idézetként” Papp Tibor egy kötetnyit mégis kiemelt mutatóba. A versgeneráló program által létrehozott alkotások nemcsak az időmértékes formát prezentálják, de költói igényességról is tanúskodnak:

Vár a világ! Magyarország jókedvét szavatolni...

tedd rá életedet! Tárd ki a kedv erejét! (7326. disztichon)

Tép a hideg! Laza ország kedv-ficamát renoválni...

lenne a tennivalód. Gyürd le a kételyedet! (7337. disztichon)

${ }^{22}$ Alexandre Gherban és Papp Tibor beszélgetése 2008 szeptemberében jelent meg a Poezibao címú internetes folyóiratban. Lásd: http://poezibao.typepad.com

${ }^{23}$ Papp Tibor - Prágai Tamás: A pálya mentén. Budapest, 2007, Napkút Kiadó, 196. 
Minden mú jelentése az olvasatok sorozatából áll össze, s minden próbálkozás, megközelítés újabb és újabb jelentésrétegeket tárhat még fel. Vagyis az esztétikai tapasztalat kommunikatív cselekvési mozzanatokból áll, s az ún. „nyitott múvek” Umberto Eco szerint - elóhívják a kreativitást: az értelmezés során egyrészt feltárul a múvek gazdagsága, másrészt az olvasók újra is írják az olvasás során a szöveget. Ezzel szemben úgy túnik, hogy a szoros szerkezetú „zárt múvek” már nem kínálnak választási lehetốséget a befogadónak. Csakhogy - mondja erre Eco - a nyitott szöveg az, amely „zárt programot ír elő szerkezeti eleme, a Mintaolvasó számára”, s éppen a zárt mú engedi meg a szöveg szabad használhatóságát. ${ }^{24}$

A disztichon zárt formai szerkezete is újabb és újabb értelmezói horizontot nyit meg az interpretáció során. A fenti példánkat, a 7326. és a 7337. disztichont olvashatjuk úgy is, mint ugyanazon mú két olvasati variációját. A hexameterek és a pentameterek ugyanis nemcsak szerkezetileg, ${ }^{25}$ hanem tartalmilag is "lefedik” egymást: a szöveggenerálás során szinte az értelmezési megoldások, az olvasatok is generálódnak. Az ellentétek (vár a világ / tép a hideg; jókedv / kedv-ficam; ssavatolni / renoválni; kedv ereje I kétely), a haza megnevezései (Magyarország / laza ország) ugyanazon dolog két pólusát mutatják. S ebben az elidegenítố gesztusban találhatja meg az interpretátor az üzenetet: állandóan renoválni-szavatolni, szavatolni-renoválni kell. Politikai üizenet? Az is. De nem csak az. Társadalmi, gazdasági és legfóképpen erkölcsi. S ezt a napjainkban különösképp aktuális üzenetet jól be kell vésnünk, ugyanis a számmal címzett disztichonok élete maximum másfél percig tart csupán, aztán örökre eltúnnek - több millió évünk ugyanis nincs az újraolvasásra -, s a virtuálisan jelen levố 16 billió alkotás közül új kerül a képernyơre. Hiszen ha a program elindul, a csillagok születéséhez hasonlóan a generált versek száma is gyarapodni fog: eggyel, kettővel, hárommal... százzal. Az olvasót ezáltal is a versteremtố aktus részesévé teszi a költố, hiszen nélküle - az olvasó nélkül - a vers soha nem öltene látható formát.

A versgenerátor múködése során a program egy üres disztichonszerkezetbe véletlenszerúen választja be a szószedetból a szavakat. Tehát elớre egyetlen egy disztichon sincs megírva! Papp Tibor huszonnégy, szavakkal kitöltetlen disztichonsémát alkotott, majd minden üreshely-pozícióhoz szózsákokat rendelt, amelyekben minimum tíz szó található, de elófordul kétszáznál több szóelem is. A program elindításakor a véletlenszerúen kiválasztott szerkezet pozícióiba ezekból a zsákokból választódnak ki, ugyancsak véletlen útján, a szavak. A költố a véletlen irányításával gondoskodott arról is, hogy a 16 billió disztichon mindegyike értelmes, esztétikailag élvezhetô legyen: az elemek közötti összeférhetetlenséget egy feltételes paranccsal küszöbölte ki: ha valamelyik elem a lehetốségek zsákjából már bekerült az adott disztichonba, akkor ez a parancs az azzal összeférhetetlen elemek felhasználását tiltja. A versgenerátor múködését a költô egy ábrával szemlélteti: az egyik disztichonszerkezetének tizenegy pozíciójára hét-hét szót rendelt. A variációs lehetôségek száma tehát 7." Ebból a csekély mennyiségból közel kétmilliárd különbözố disztichont lehet generálni (lásd az 1. számú ábrát).

${ }^{24}$ Umberto Eco: 'The Role of the Reader. In Jonathan Culler: Dekonstrukció. E.mélet és kritika a strukturalizmus utín. Budıpest 1997, Osiris Kiadó, 98.

${ }^{25}$ A szerkezeti megegyezés tényét nem érintik a hexametersorok 4. verslábának, illetve a pentametersorok 1. ütemének az eltérései (spondeus, daktilus). 
A versgenerálás sémája

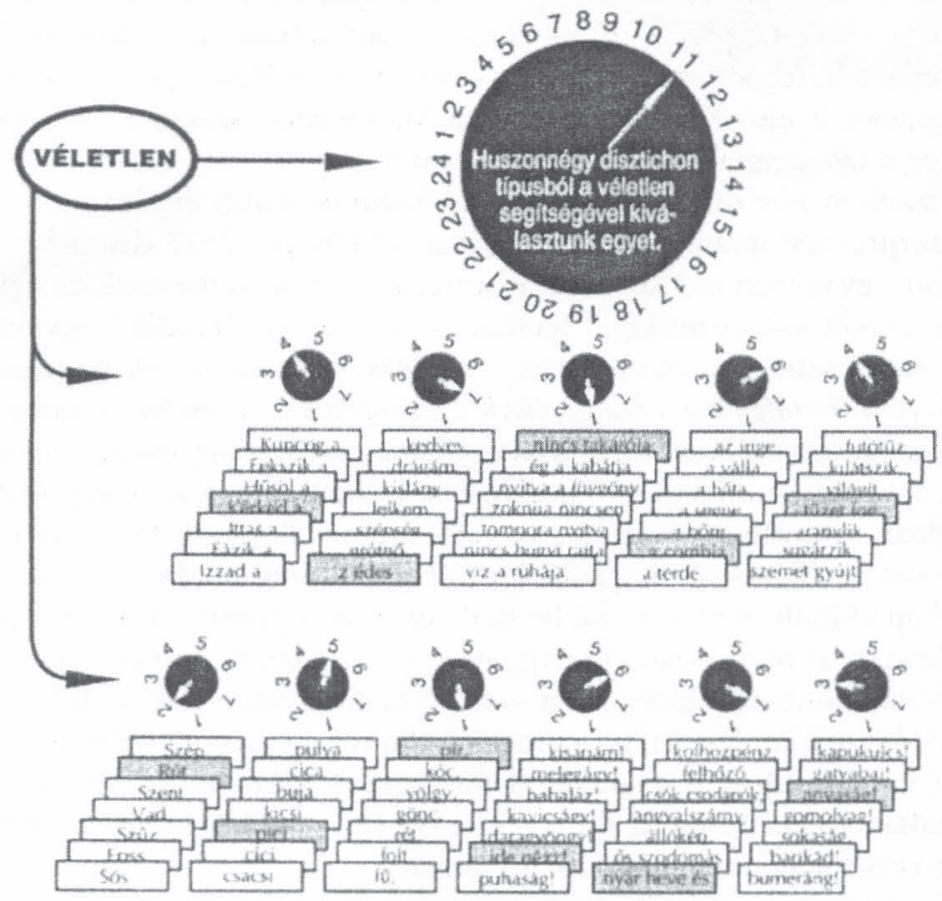

Kérked az édes, nincs takarója, a combja tüzet fog. Rút pici pír, ide nézz! nyár heve és anyaság! 


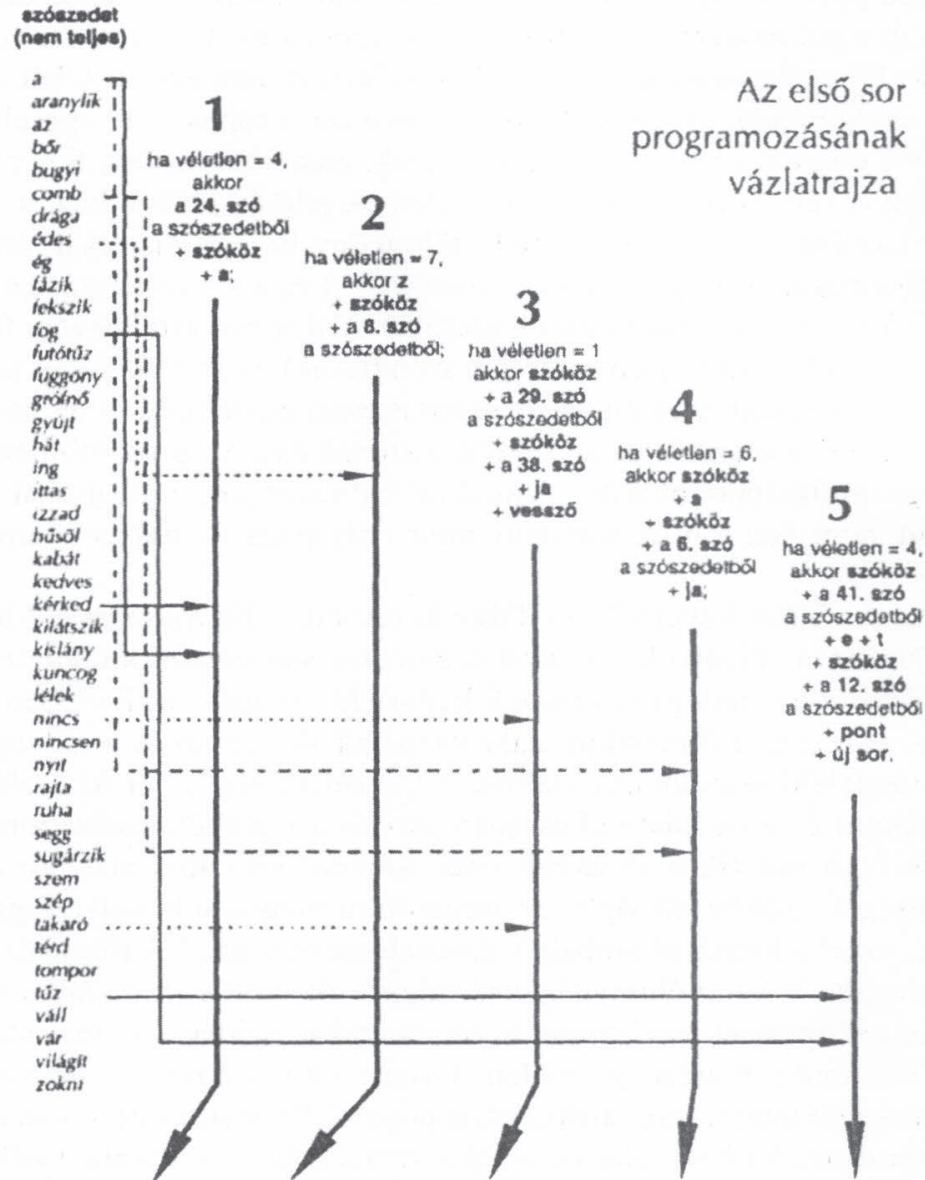

Kérked az édes, nincs takarója, a combja tüzet fog.

$1 / \mathrm{b}$ ábra

Forrís: Papp Tibor: Disztichon Alfa. Párizs-Bérs-Budapest, 1994, Magy'ar Mühely Kiudó, 26-27.

\section{A számítógépes program és a gondolati versgenerálás}

A konkrét és a spacialista ${ }^{26}$ költészetnek az 1950-es években jelentkező képviselói radikálisan szakítottak a lineáris írással és annak megszerkesztett mondattanával: a szintaxis térbeli kapcsolatok sorozatává alakult át, s az idốre épuiló klasszikus lineáris

${ }^{26}$ A konkrét költészetnek (a francia nyelvben megnevezett) formája a spacializmus, amelyet Pierre Garnier teremtett meg, s nevezett el. Pierre Garnier: Plan pilote fondant le spacialisme. In les L.ettres, no. 31, 2, Párizs, 1965, André Silvaire. Lásd még Philippe Minguet: Le Sycomore. In Écritures. Párizs, 1982, 121. 
mondattant, a kronoszintaxist felváltotta a toposzintaxis, amelyben az idő már egészen másfajta szerephez jut. Így a konkrét múvekben az elsôdleges esztétikai hordozóeszköz már nem a szó mögöttes jelentése lett, hanem „a nyelv nyersanyaga, a leírt szó a maga direkt közvetlenségében". ${ }^{27}$ A térbeli költészet semlegesíti tehát a szöveg időbeliségét, alkalomadtán megfordíthatóvá is teszi azt, s topológiai kapcsolatokat létesít a nyelvi jelek elemei, a betúk, szótagok, szavak, mondatok között. S nem létezik sem nyelvtankönyv, sem szótár, amely „ezen elemek jele és jelöltje között pontos stabil kapcsolattal szolgálna". Így egy térbeli költemény befogadója olyan átmeneti pozícióban találja magát, amely ,a szöveg olvasója [...] és a kép értelmezóje [...]” között jön létre. ${ }^{28}$ (A szöveg olvasója betúket, szavakat talál, a kép értelmezôje formák és színek két dimenzióban való elrendezésével szembesül.) Az ilyen konkrét szabályok szerint létrehozott mú már nem mutat be semmit, nem beszél valamiról, hanem vizuális, verbális és hangbeli elemeinek, a színnek, a szónak és a hangnak mint önmagára utaló jelnek a megvalósítására törekszik. ${ }^{29} \mathrm{~A}$ konkrét költészet tárgya tehát saját maga, hiszen „nem mond, nem akar többet mondani, mint saját maga, »tartalma a forma és formája a tartalom «". ${ }^{30}$

A Disztichon Alfát követô Papp Tibor-kötetben, a Vendégszövegek 4-ben (1995) az új formák között (a „hínárzók”, a spirálok és az ún. sorjázóversek mellett) feltúnnek a konkrét költészet egy jellegzetes típusát képviselő „gyúrúk” is. Ezekben a múvekben a formához, azaz a gyúrú mágikus alakzatához alkalmazkodnak a szövegek. A gyúrú a körnek megfelelő szimbolikus alakzat: a folyamatosság, az örökkévalóság jelképe. A kört a platóni és a neoplatonikus gondolkodás a legtökéletesebb formának tartja. Ezért túnik fel a misztikus ábrákban Isten körként való ábrázolása is: a Mindenható végtelenségét, örökkévalóságát, az abszolútum megragadhatatlan fogalmát az ember számára ezzel a formával próbálják érzékelhetôvé tenni. ${ }^{31}$ A tükrözés elvére épülő grafikai alakzatba, a szimbólumvilágokat megjelenítố körbe írt irodalmi szöveg akár a végtelenség jelképeként értelmezve új horizontokat nyithat a befogadói rekonstrukció során. S számos jelentést generálhat! Hiszen a körnek nincs kezdete, nincs vége, „nem ad meg sem irányt, sem tájékozódási pontot”, ${ }^{32}$ vagyis akárhonnan elkezdhetjük olvasni a mondatot. S a határtalanságot fokozza is a költố: számos alkotásában ugyanis a gyưrú kinyílik, s a végtelen felé mutat. A bezártság, a rendezettség „végtelensége” és a megnyitás, a kinyílás így fejezheti ki ugyanazt a princípiumot (lásd a 2. számú ábrát).

\footnotetext{
${ }^{27}$ Martos Gábor ezekkel a jegyekkel határozza meg a konkrét vers fogalmát. Lásd Kép(es) költészet. Kisérleti irodalmi olvasó- és nézökönyv. Sopron, 1995, Patriot Kiadó, 92.

${ }^{28}$ Francis Edeline: Le logo mandala. Centre Interdisciplinaire d'Études Philosophiques de l'Université de Mons (Ciéphum), Belgique. Cahiers Internationaux de Symbolisme, 48-50, 1984, 205. Fordította Papp Nóra. (Elsố magyar közlés.)

${ }^{29}$ Szombathy Bálint: A konkrét költészet útjai, II. Új Symposion, 147-148. számok melléklete, 2.

${ }^{30}$ L. Simon László: Hidak « Dunán. Esszék tanulmányok. 2005, Ráció Kiadó, 90.

${ }^{31}$ Hans Biedermann: Knaurs Lexikon der Symbole. München, 1989, Droemer Knaur. Ford. Havas Lujza - Körber Ágnes. Szimbólumlexikon. Budapest, 1996, Corvina, 138, 224-225.

${ }^{32}$ Hans Biedermann: i. m. 225.
} 


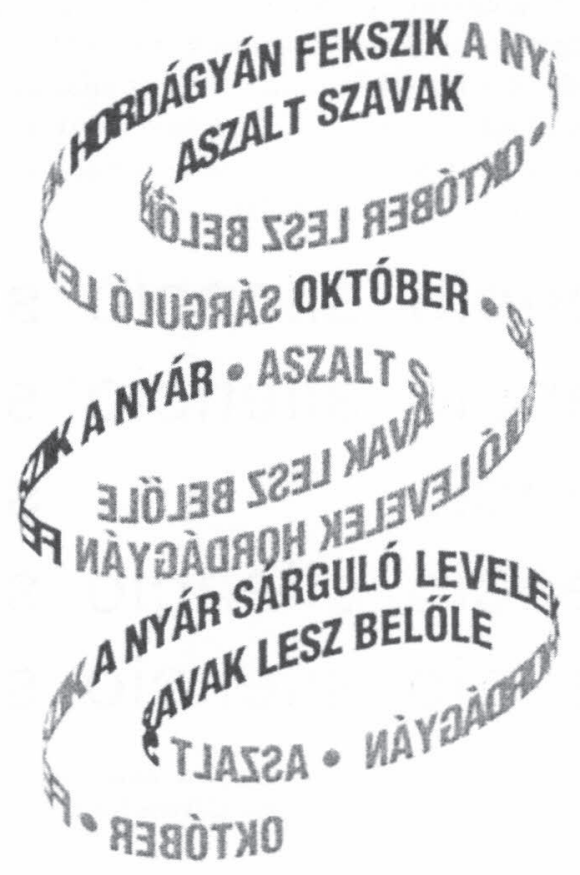

2. ábra

Forrás: Papp Tibor: Vendégszövegek(n). Budapest, 2003, Ister Kiadó, 488.

A konkrét múvek csoportjába sorolhatjuk a Vendégszövegek 5 címú kötet logomandaláinak a poétikai struktúráját is, amellyel Papp Tibor egy új vizuális meditatív múfaj magyarországi meghonosítója lesz. A görög logosz és a szanszkrit mandala szavak összevonásával Francis Edeline által elnevezett modern költészeti formát ugyancsak a konkrét és spacialista költớk tették Európa-szerte ismertté. Az elnevezés görög szóeleme abból a felismerésból született, hogy minden költemény - a hagyományos formájú és a vizuális költészeti alkotás egyaránt - az anthroposzt, a kozmoszt közvetíti, a mandala utótag pedig a közvetítés topológiai szerkezetek általi megvalósulását jelzi.

Francis Edeline az 1990-es években a térbeli költészetet képviselố negyven költố életmúvéból kilencven azonos kritériumok alapján kiválogatott konkrét múvet tett közzé. A kötetben szereplő vizuális költemények toposzintaxisa alapvetóen szimmetrikus kapcsolatokon, megfordíthatóságokon, derékszögú tengelyeken, azaz a középponton alapszik, a domináns alakzat pedig elsôsorban a kör vagy a négyzet, esetleg a kettô változata. A gyújteményben elófordulnak még téglalapok, rombuszok, vagy olyan geometriailag teljesen szimmetrikus alakzatok is, amelyek csúcsát különböző szavak foglalják el. Az alakzatokat pedig nem vonalak, hanem betúk vagy szavak egymásutánisága építi fel.

Papp Tibor szókörei azonban az edeline-i kategóriától innovatív módon eltérnek. Konkrét versei ugyanis „alig felelnek meg azoknak a kategóriáknak, melyeket Edeline a logomandalák rendszerezésére kialakított". ${ }^{33}$ A Francis Edeline által összegyújtött és ${ }^{33}$ Kelényi Béla: Szó-körökben körbeszéd. Papp Tibor logomandaláiról. Új Forrús, 30. évf., 1998, 5. szám, 48. 
bemutatott logomandalák egyike, Eugen Gomringer téglalap alakzatú, Schweigen címú alkotása is a különbséget szemlélteti. Gomringer a múvét számtalan nyelvre lefordította. Valójában a konkrét vers lényegét nem érinti, az alkotást nem módosítja a fordítás: mindegy, hogy milyen nyelven olvassuk. A silencio (vagy akár Schweigen) szó szabályos ismétlése egy zónát, egy felületet hoz létre, nevezetesen egy olyan téglalapot, amelynek középpontja üres (lásd a 3. számú ábrát).

\section{silencio silencio silencio silencio silencio silencio silencio silencio silencio silencio silencio silencio silencio silencio}

3. ábra

Forrás: Eugen Gomringer: Schweigen. (Francis Fideline: Le logo mandala. Centre Interdisciplinaire d'Études Philosophiques de l'Université de Mons [Ciéphum], Belgique. Cahiers Internationaux de Symbolismc, 48-50, 1984, 213.)

Papp Tibor logomandalájának a legfóbb jellegzetessége viszont az, hogy „kör vagy négyzet alakú, középpontja van, szimmetrikus, olvasata a tengelyek mentén megfordítható, szavai sokszor visszafelé is olvashatók". ${ }^{34}$

Az olvasatok sokféleségére utalva Kelényi Béla szerint a költő „egyfajta vers-generátorként" használja a mandalaelvet. ${ }^{35} \mathrm{~S}$, ,a »mandala "rendszerének felidézése csupán ürügy arra, hogy mindenáron megpróbálja megkérdójelezni” az új múfaj „rendszerében kimondhatatlan szó jelentésének állandóságát. [...] a nyelv labirintusában eltévedve, egy végtelenített „szó-mezóben” a szavak folytonosan csak új kapcsolatba kerülhetnek egymással. [...] ebben a labirintusban sohasincs megérkezés, a szó, végső soron a logosz soha nem érheti el végleges jelentését". ${ }^{36}$

A Hallod címú logomandalában például a tapasztalat, a költői fikció medializálódása, egyik médiumból a másikba való átfordítása rekonstruálható. A költối szó-, kép- és értelemteremtés az írásnak, a szerkesztésnek a médiumán keresztül egyrészt verbalizálódik (érzékelhetôvé, hangzóvá válik a befogadó által az olvasás során és a „hallod” ige centrális helyzetével), másrészt a tizenhat sugarú középpont képisége vizuális élményt is ad. A szem - mint minden logomandalában - szabadon ugrálhat egyik észlelési pont-

${ }^{3+}$ Papp Tibor: Vendégsä̈üegek .5. Budapest, 1997, Magyar Múhcly Kiadó, 5.

${ }^{35} \mathrm{Az}$ olvasatok számos variációja miatt akár a logomandaláknál is hašnálhatnánk a számítógép szerzới utasításait („,ha meg akarja indítani a programot”, „, ha az olvasási időt hosszabbítani óhajtja”). Kclényi viszont a számítógépen generált költemények és a logomandalák közötti különbségre is felhívja a figyelmet: a gép megállított programja csupán a számtalan változat egyikét adja meg, a logomandalák olvasatai azonban egy idố után kimerülnck. Lásd: Kelényi Béla: i.m. 48-50.

${ }^{36}$ Papp Tibor logomandaláinak nyelvlabirintusát Kelényi Béla egy Borges-novellával állítja párhuzamba, Az elágazó ösvények kertjével. Kelényi Béla: i. m. 50. 
tól a másikra, és „átadhatja magát” a költemény formájának, a globális megértésnek. Francis Edeline „a szem vakációjának” (vacance de l'œil) nevezi ezt a jelenséget: a szem kevésbé van a sor követésére kényszerítve, annál inkább alá van vetve „a vonzás és összpontosítás észlelőmechanizmusának". Ezek az észlelőmechanizmusok a nyelvi egységek jelentésére (,,a menekülések és vonzások tárgyaira”) reagálnak, és „,bizonyos szimmetriák megfelelố használatával" meghatározzák az ún. hallucinációs effektust, az érzéki csalódást. ${ }^{37} \mathrm{Az}$ auditív élmény, a hang forrása (akit vagy amit hallunk, hallgatunk) hangszínképzetet idéz fel a befogadóban a költészeti meditáció során. A próféta, a szívverés, a hiábavalóság vagy a farkas hangja, szava ugyanis egészen másként hat, ha a kútból, az égból, a gốzvezetékból ered, vagy akár a kezünkön át jut el hozzánk, vagy ha a fa alatt, a túzhely mellett, esetleg mindenütt halljuk a költói üzenetet. Az üzenet tartalmát viszont a befogadónak kell megfogalmaznia. S ebben a befogadói-alkotói folyamatban a nyelvi alapú gondolkodás korlátai, határai is kirajzolódhatnak (lásd a 4. számú ábrát).

\section{HAILIOD}

kezeden át

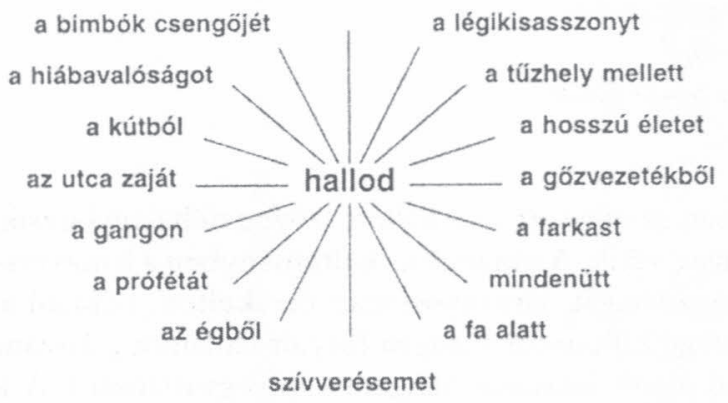

4. ábra

Forrás: Papp Tibor: Vendégszövegek(n). Budapest, 2003, Ister Kiadó, 586.

\section{Számítógéppel generált dinamikus kép-, szöveg-és hanguersek}

A logomandalák után 2000-ben ismét az automatikusan generált versek következnek Papp Tibor életmúvében. A Hinta-palinta címú dinamikus költemény az új médiumnak, a számítógépnek a lehetôségeit viszont már sokkal gazdagabban mutatja be. A generált verseken, szövegeken kívül ugyanis a szerző vizuális költeményeket és hangverseket is létrehoz a megalkotott programmal. A megnyitott CD - miután ízelítốt ad a programból - négy ikont jelenít meg a képernyốn: a generált vers jelzésú ablak a szeretett nô iránti Hódolat felezố tizenkettesekból alkotott tizenhat soros, tömbszerú kompozíciójából ad egy változatot, a második ablak néhány másodpercben audiovizuális, kinetikus effektusokat jelenít meg enyhén pornográf elemekkel, a még? jelzésú ikon

${ }^{37}$ Francis Edeline: i. m. 208-209. 
a dinamikus kép-, hang- és szövegkompozíciókhoz való visszatérés lehetôségét rejti, a negyedik ablakra, a vége feliratra kattintva pedig bezárhatjuk a programot. A még? egyik dinamikus költeményében, a rózsaszín-fehér felület alsó harmadában egy keskeny fehér sáv húzódik végig. A sávban jobbról balra, egy nói fej irányába fut a központozás nélküli folyondárszerú szöveg:

„gyorsuló mályvaillat a reggel felhördülnek a gyári trombiták még álmos gyúrött a föld reped az ég a tenger fölött sárga szíjakat hasít a szél a vízból szobrokat farag a gyorsuló mályvaillat a reggel fölhördülnek a gyári trombiták még álmos gyưrött a föld"

A vizuális költemény megjelenésével párhuzamosan polifon szerkesztésú, idônként echoszerú hangverset hallunk:

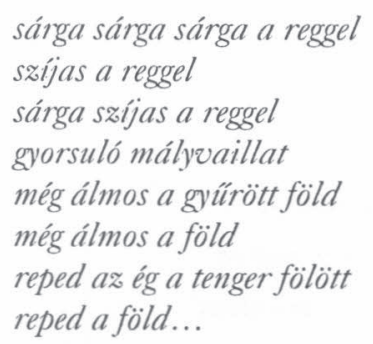

A folytatásban az olvasott és a hallott szöveg néha egybeesik, azaz a divergens viszony konvergenssé válik. A dinamikus költeményben a hangvers- és képversgenerálás gazdagságát (hangzósságát, látványosságát) érzékelteti, például a megjelenố klaviatúra, amelynek mozgó billentyưi susogva fütyült dallamot „játszanak”, a képelemekkel kísért „köldököd alatt” kezdetû hangvers szövegvariánsai („A köldököd alatt a legjobb falat domborodik a hasad a köldököd felett Kilimandzsárót lát a képzelet duzzadó melleket a köldököd alatt / a köldököd alatt a legjobb falat domborodik a hasad...”), vagy egy nói akt képének a „szétvágása”, majd részenkénti összeillesztése, illetve újra elválasztása, amelynek erotikusságát fokozza az ,ahonnan hegyeidet, völgyeidet látni, csodálni lehet” ismétlődő hangversszöveg és a különböző hangmagasságban megszólaltatott vibrációs énekhang. A múzeum elôtt életre kelt nói szobor, valamint a hozzárendelt hangeffektusok és monitorra írt szövegvariánsok is jelzik: a grafikai elemeket az írott szöveggel és a hangverssel keveri, variálja (számos változatban generálja) a számítógép. ${ }^{38}$ Bár a költő A Hinta-palinta šöveghordalékából 2000-2001 címú kötetében ad ízelítőt a múból, a Hódolatokat is bemutatva, a még? dinamikus költeményeihez hasonlóan most sem a könyvból idézek, hanem a generált versek még le nem jegyzett sorozatából mentek ki egyet a papír grafoszférájára:

${ }^{38}$ Papp Tỉbor francia nyelvû dinamikus képversgenerátorai, az Orion (1999), illetve a Claude Maillardral közösen alkotott Ein hâte (2002) ugyancsak erre az effektusra (a grafikai elemekre, valamint a szöveg- és a hangversgencrálásra) épülnek. 
tisztelem a csípöd kora esti táját
nyárig a hadakkal rendezem a sarcot
kókemény zsemlének nincs hajasbabája
örömödre hajlik érseklila mályva
kökény magot nyeltem zabolátlan lettem
hozzád hasonultam én is csatahajó
angyalom ki látja hol a csoda vége
s hogy ha nem hínálak eljönnél-e vélem?
ha múlékony lennél mint tü: a pincében
akkor is apródként káromkodnék érted
kinek köszönjem meg hogy tapogathatlak
s nyálad kóstolhatom a fényzuhatagban
illatos mondatok forognak fejemben
bevonulok csendben bársony börtönödbe
nevetésed hallva megenyhïl a végæet
jóságod peremén boldogságom ébred

(81093 265. hódolat)

A felező tizenkettes már a középkor végi szövegemlékeinkben megtalálható (lásd: Geszti László éneke, 1525; Apáti Ferenc Cantilénája, 1526). ${ }^{39}$ Szótagszám és sormetszet tekintetében „éppoly kész típusa a sorfajnak Balassi tizenkettőse, akár a Gyöngyösié s a Mohács körüli és utáni verselőké". ${ }^{40}$ A tizenkettes szótagszámú versforma Zrínyi korára már általánosan uralkodóvá váltt. ${ }^{41} \mathrm{~S}$ hogy ez a 6+6-os cezúra magyar előzményböl, egy szabad szótagszámú négyütemes sorból vált-e ki, vagy készen vettük át a latinból, esetleg dallam közvetítésével más idegen költészetböl, vagy eredetileg két hatos sorból forrott össze, mindez lényegtelen, hiszen a forma ősiségét nem érinti, csak erősíti. Papp Tibor tehát itt is - csakúgy, mint a Disztichon Alfa esetében - az irodalomtörténet testéhez, az ősi versformákhoz szorosan kapcsolódva, kötött formájú versszerkezeten mutatja be a versgenerálás mediatív terét. Ezek a számítógéppel generált versek és vizuális költemények egyben felvetik a mü létezési formájának kérdését is: „hol található a mü valójában”? Bodor Béla szerint a müvek egy része papírra nyomtatva jelenik meg, s ,ezek a szövegek bekerülnek a beszédközönség olvasói diskurzusába”. Másfelöl „ott van a mü, ahol szókészlete és szabályrendszere feltárul az olvasó elött”. Ehhez viszont már a befogadó aktivitása szükséges. A feltáró müvelet ugyanis a program megismerését is jelenti. Autentikus olvasat csak igy készíthető azokról a müvekről, amelyek nem azonosíthatók ,,egy mủtárggyal, egy szöveggel vagy egy kottaképpel”, hanem ,az olvasatokat konfrontáló polémiában” létesülnek. ${ }^{42}$

Annick Bureaud az Art Press címú francia múvészeti magazinnak az ezredfordulón megjelent számában három irányt különít el a világháló által megújult numerikus irodalomban. Az első irányt nevezhetnénk akár ,kibertéri falfirkának” (graffiti cyberspatial)

${ }^{39}$ Horváth János: A középkori magyar vers ritmusa. In Korompay H. János - Korompay Klára (szerk.): Horviath Jänos verstani munkóii. Budapest, 2004, Osiris Kiadó, 289.

${ }^{40}$ Horváth János: Gyöngyösi és Arany sormetszete. In Horvaíth Jínos verstani munkái. i.m. 316.

${ }^{41}$ Horváth János: A magyar vers. In Horvaíth Jänos verstani munkáii. i. m. 476.

${ }^{42}$ Bodor Béla: i. m. A szerzô szerint „nem a hordozó hordozza a múvet, hanem a diskurzus, amit generál”. 
is. Az idetartozó múvek a szöveg-, a hang- és a vizuális elemek teljes fúzióját jelenítik meg. Vannak olyan múvek is, amelyek az internet nyelvezetét és kódjait használják. Theo Spiller Poem 2 címú verse például a szörföző által megragadott mondatot alakítja át egy hipertextuális mondattá. A harmadik irányt pedig az alire 11. számában közölt múvek jelzik: új képernyôs kultúra van születốben, amelynek képviselóje Papp Tibor - mondja Annick Bureaud.

A költő egymásra tolt képernyóin olyan szereplóket látunk, akik elhagynak egy mozivásznat azért, hogy a számítógép monitorján folytassák az életüket, ahol dialógusablakok jelennek meg megszakításokkal, s „a szerzónek oly kedves irodalmi kínálat (étlap) úgy gördül le eloóttünk, mint egy színpadi függöny". Másutt a textualitást, a beszédet rádió- vagy televízióadások, reklámok törik meg. A szerzố ezekkel az alkotásokkal „különböző szintű szövegeket, jelentéseket és tereket szô”. ${ }^{43}$

„Számítógépen készült irodalmi mú akkor és csak akkor igazolja számítógépes mivoltát [...], ha szerkezeti felépítésében legalább egy olyan alkotóelem található, amelyet nem lehet [...] csak számítógépen létrehozni" - írja Papp Tibor a Mízsával vagy mísa nélkiil? címú könyvében. ${ }^{44}$ Ilyen jellegzetes alkotóelem lehet a kombinatorikai eszközök alkalmazása, a véletlen szerepe a mú létrejöttében vagy az olvasó és a mú közötti „párbeszéd”.

A kombinatorika alkalmazása nem más, mint a betöltésre váró üres szerkezetek kiválasztása, az egyik elem beillesztése a másik után, a szavak helycseréje, permutációja. Ez a szerkesztésmód kezdettól fogva a költối alkotóattitû́d jellemzó sajátossága, hiszen egy vers születése is választást, döntést, az elemek eredeti szerkezetté való összeillesztését jelenti. E proteikus formára az első figyelemre méltó példákat a barokk kor német irodalmában találjuk: Quirinius Kuhlmann 43. szerelmes csók címú versében például a szavak helyét a soron belül tetszés szerint felcserélhetjük. A számítógép megjelenése elốtt e kombinatorikus formák sorát Raymond Queneau 1961-ben megjelent Százezer milliárd költeménye zárja. Az új médium megjelenése ezt a proteikus formát tette teljessé azáltal, hogy az üres szerkezetekból és a halmazok egyedeiból végtelen számú, emberi befogadásra alkalmas múvet képes generálni.

A másik jellegzetes jegy a véletlen, amellyel az irodalmi mú minden szerkezeti elemét összekapcsolhatjuk. A megtervezett véletlen mellett, amelyról a Disঞtichon Alfa bemutatásakor írtam, értelmetlen olvasatok is elófordulhatnak ugyan, de a véletlennek ez a kiszámíthatatlan volta, eseményt szimuláló ereje csak még inkább fokozza a befogadói feszültséget, az egymás után születő alkotások iránti érdeklődést.

Az egyedül csak a számítógépen készüilt irodalmi múvek harmadik sajátossága a párbeszéd, pontosabban a „,beleszólás joga” (Papp Tibor): a befogadó leállíthatja, újraindíthatja a programot, választhat a felkínált ikonok, szerkezeti elemek közül, s ez a választás egyszeri és egyedi, soha meg nem ismételhetô változatot hoz létre.

A francia szellemtudományi diskurzusok egyik jelentős teoretikusának, Maurice Blanchot-nak alapvetó tézise, miszerint a mú maga is kommunikáció, meghasadt bensôségesség, amelyben „a kezdet léte és a határozatlanság, az újrakezdés léte harcol egymással", a számítógépes irodalomban még inkább nyilvánvalóvá válik. Az irodalmi

\footnotetext{
${ }^{43}$ Annick Bureaud: uo.

* Papp Tibor: Múzsával vagy múzsa nélkiul? Budapest, 1992, Balassi Kiadó, 167.
} 
tér címú kötetében közölt írásaiban Blanchot kiemeli a befogadó szerepét: az olvasó azt hiszi, hogy nincs rá szükség, miközben „ố teszi a múvet azzá, ami. Viszont a mú távol is tartja magától az olvasót, helyreállítja a távolságot, amely egyedül biztosíthatja a befogadás szabadságát, [...] e távolság a múvet eltávolítja bármiféle szerzốtól, sốt annak gondolatától is, hogy megalkották, s így akként tárja elénk, ami.” A mú a tiszta távollétet, a lét elrejtett jelenlétét ragadja meg. A létet, amely az elrejtés által van: „a lét lényegileg lét az elrejtésben" ${ }^{45}$ Blanchot ezzel az irodalmi mú ontológiai prioritását állítja, s ezzel eloldja a szöveget mindenféle külsố determinációtól. ${ }^{46}$

A számítógéppel generált költeményeket vizsgálva a blanchot-i „irodalmi tér” erôvonalai még inkább érvényre jutnak. Ezeket a múveket az első megközelítésben úgy kell olvasnunk, esztétikailag úgy kell megragadnunk mindegyiket, mint egy klasszikus értelemben született verset. Az interpretáció során viszont erról az elemzó síkról tovább is kell lépnünk, hiszen ezek a költemények összevethetók ugyan a papírra nyomtatott, látszólag hasonló jellegú irodalmi alkotásokkal, és komparatív módon elemezhetók is, ezek a megközelítések mégis éppen a lényegi sajátosságaiktól, múfaji jellemzốiktól fosztanák meg az új médium által hordozott és általa létrehozott múveket. A generált versek léte ugyanis éppen a virtualitásban, illetve életre keltve a tünékenységben rejlik: ezek a múvek az irodalomelméleti kérdéseken túl filozófiai-ontológiai síkra terelik az értelmezô-elemzố gondolkodást, s az emberi lét teljességét, a létnek az elmúlás után új dimenzióba kerülését aposztrofálják.

${ }^{45}$ Maurice Blanchot: A mú és a kommunikáció. In Az irodalmi tér. Ford. Lốrinszky Ildikó. Budapest, 2005, Kijárat Kiadó, 166-76, 246, 5. lábjegyzet.

46 Kálai Sándor: „Tiszta belsô égés a semmi körül”. Maurice Blanchot: Az irodalmi tér. Magyar Mühely, 136,44 . 